\title{
Optimizing the Ability of Aceh Province in Paradiplomacy Practice
}

\author{
Risky Novialdi ${ }^{1}$, Saddam Rassanjani ${ }^{2}$ \\ ${ }^{1}$ Department of International Relations, Al Muslim University, Bireuen - Indonesia \\ ${ }^{2}$ Department of Government Studies, Universitas Syiah Kuala, Banda Aceh - Indonesia \\ Email: hera.aldyra@gmail.com \\ Submitted: 15 June 2020 | Accepted: 30 June 2020
}

\begin{abstract}
This paper analyzes the opportunities for the development of Aceh province in the era of globalization. Paradiplomacy is one of the efforts that can be utilized to develop the Aceh province. Based on the Constitution Number 11 of 2006 on the Aceh government, has given Aceh province considerable authority to develop its territory, including establishing diplomatic relations with the regions others abroad through the Paradiplomacy practice. But, with this considerable authority, Aceh is still the poorest region in Sumatra and the poorest number 6 in Indonesia based on the statistics centre data (BPS) in 2019. This means that Aceh still fails to exploit its social and natural conditions for the development of its territory. In This research we used qualitative method, by gathering previous studies through observation, interviews and data collection. Aceh could utilize the "Tsunami Disaster" to become the initial capital to practice paradiplomacy with other regions abroad. Actually Aceh also has other capital, namely as a former conflict area and also as the best coffee producer in the world. Therefore, Aceh has at least three large capitals to establish cooperation with foreign parties through the paradiplomacy practice, with the concept of sister Province, Sister City.
\end{abstract}

Keywords: Globalization, Paradiplomacy, Aceh, Province, Sister, City.

\begin{abstract}
Abstrak
Artikel ini menganalisis tentang peluang pengembangan provinsi Aceh di era globalisasi. Paradiplomacy adalah salah satu upaya yang dapat dimanfaatkan untuk mengembangkan provinsi Aceh. Berdasarkan Undang-Undang Nomor 11 Tahun 2006 tentang pemerintahan Aceh, telah memberikan kewenangan yang cukup besar kepada provinsi Aceh untuk mengembangkan wilayahnya, termasuk membangun hubungan internasional dengan daerah-daerah lain di luar negeri melalui praktik Paradiplomacy. Tetapi, dengan wewenang yang cukup besar ini, Aceh masih merupakan wilayah termiskin di Sumatra dan nomor 6 termiskin di Indonesia berdasarkan data pusat statistik (BPS) pada tahun 2019. Ini berarti bahwa Aceh masih gagal mengeksplorasi kondisi sosial dan alamnya untuk pembangunan. Dalam penelitian ini kami menggunakan metode kualitatif, dengan mengumpulkan studi sebelumnya melalui observasi, wawancara dan pengumpulan data. Provinsi Aceh dapat memanfaatkan "Bencana Tsunami" untuk menjadi modal awal untuk mempraktikkan paradiplomasi dengan daerah lain di luar negeri. Provinsi Aceh juga memiliki modal lain, yaitu sebagai daerah bekas konflik dan juga sebagai penghasil kopi terbaik di dunia. Karena itu, Aceh memiliki setidaknya tiga modal besar untuk menjalin kerja sama dengan pihak asing melalui praktik paradiplomasi, dengan konsep Sister Province atau Sister City.
\end{abstract}

Kata Kunci: Globalisasi, Paradiplomasi, Provinsi Aceh, Sister City.

\section{INTRODUCTION}

In the era of globalization, provinces in a country cannot only rely on the central government to carry out development in the regions. But the 
local government itself must be actively involved in carrying out development including establishing cooperation with foreign countries. The participation of local government or the autonomous region to take part internationally, according to Stefan Wolff (2007) indicates that the most basic ideas on the state sovereignty have changed fundamentally. The Westphalia system which puts the sovereignty solemnly on the central government must be willing to share with the local government for its concept of international activities. On how much the proportion of shared sovereignty must be distinctive among the states (Wolff, 2007).

Diplomacy is an essentially political activity and, well resourced and skilful, a major ingredient of power. Its chief purpose is to enable states to secure the objectives of their foreign policies without resort to force, propaganda, or the law. It follows that diplomacy consists of communication between officials designed to promote foreign policy either by formal agreement or tacit adjustment. Though it also includes such discrete activities as gathering information, clarifying intentions, and engendering goodwill, it is thus not surprising that, until the label 'diplomacy' was affixed to all of these activities by Edmund Burke in 1796, it was known most commonly as 'negotiation' - by cardinal Richelieu as négociation continuelle. Diplomacy is not merely what professional diplomatic agent does. It is carried out by other officials and by private persons under the direction of officials. It is also carried out through many different channels besides the traditional resident mission. Together with the balance of power, which it both reinforces and reflects, diplomacy is the most important institution of our society of states (Berridge, 2015).

As the development of actors in the science of international relations, actors also change in diplomacy, so that those who play a role in the interaction between other countries or other parties abroad also develop, can be done by actors who have been given authority by the central government. One of them is the role of sub-countries such as the Province or even a city. Cities are the oldest political entities in history and played an important political role until the Middle Ages when the advent of the nation-state in the 1500s reduced them to relatively insignificant political players. However, the growth of globalisation in the 1990s and the rapid growth of urban areas worldwide, demanding solutions for environmental degradation, public transport, housing, education, health, and public services, have once again brought cities to the political forefront 
(Rodrigues and Mattioli, 2017). But in this era of globalization, provinces and cities can develop their regions through the practice of paradiplomacy.

Paradiplomacy is a relatively new phenomenon and subject in the study of international relations. It refers to what could describe as a "foreign policy capacity" of sub-state entities, their participation, independent of their metropolitan state, in the international arena in pursuit of their specific international interests. This is a conceptually and practically challenging developmentconceptually because the discipline of international relations does not normally consider sub-state entities as subjects of international relations; and practically because states' claim to external sovereignty, their unique right to engage with other players in the international arena, is, in a sense, hollowed out and perhaps fatally undermined if they have to share this essential prerogative of stateness (Wolff, 2007).

Alexander S. Kuznetsov (2015) had a definition of paradiplomacy that could be one way for the government to share its power with the provincial government for international relations. he argued, Paradiplomacy, which often is primarily a function of stateless nationalism suggests that the processes of nationalism (identity construction, interest definition/ articulation and political-territorial mobilisation) logically lead to regional governments seeking the development of an international personality. In this way, paradiplomacy serves as a means for identity- and nation-building and sustains and promotes specific interest definitions such as cultural preservation (Kuznetsov, 2015).

Regions and cities are important international actors. If the international community has always been aware of the economic significance of some US states (such as California or Texas) or of regions using foreign policy to leverage their internal autonomy (such as Quebec or Catalonia), today the phenomenon is much more visible. Subnational governments are concerned with what has traditionally been defined as "low policy": environmental issues, investment promotion, cultural and educational exchange etc. This contrasts "high policy," represented by the diplomatic and military security agenda of a central government. In other words, paradiplomacy represents the projection abroad of the domestic competencies of subnational governments, which are predominantly concentrated on such "low policy" issues (Tavares, 2016).

The Helsinki Memorandum of Understanding (MOU) of 2005 had given the authority for the Acehnese to manage their government. They 
obtained a broad authority in the fields of domestic business, including economy, social, politics, law, culture, mining, and trade. Even more so, the Aceh government also attained the authority to engage with the foreign partnership in the frame of national governance of The Republic of Indonesia. That huge authority for Aceh governance is a part of the implementation of asymmetrical autonomous principals in Indonesia. Before the Helsinki Agreement, the government of Indonesia has produced Constitution Number 18 of 2001 on the Aceh Special Autonomy. However, this could not fulfil the Acehnese aspiration as a whole, so it cannot run well. The principals of governing Aceh' stated in the Helsinki MOU have been legalized by the national government of Indonesia as the national regulation, namely the National Law Number 11 of 2006 on Governing Aceh. The regulation has explained into the details about the principals previously do not exist in the Helsinki MOU, as well as the authority to exercise the foreign partnership or Para-diplomacy in the framework of the Unitary States of the Republic of Indonesia (Mukti, 2019).

To date, the Aceh government has been engaged in the cooperation with the foreign parties both for the governance or technical business such as with various of foreign universities from Sweden, United Kingdom, Penang Malaysia, Istanbul Turkey, and Japan. Yet of all the existed and initiative cooperation, some of it was stopped on the Memorandum of Understand (MOU) signing only, without being followed by the realization of the implementation of the agreement. Among that fact was revealed in the research done by Sahari A. Ganie (2015), the lecturer in the Faculty of Social and Political Sciences, Unsyiah, who stressed that the impression had appeared in the pattern of diplomacy handling by the Aceh government (Paradiplomacy) remains very conventional. The domination of government visits overseas, both the executive and legislative, has proven their effort to offer the investment potential in Aceh as stated in the MOU (Ganie, 2015). Unfortunately, those were ended from one MOU to another without giving any significant concrete realization (Mukti, 2019).

The findings of Sahari A. Ganie (2015) has been confirmed by the publication in the form of a report on foreign investment realization which has decreased drastically after 2013 from 1.5 trillion Rupiah of foreign investment to only 9 billion Rupiah, although there was a quite significant growth from 2010 to 2013 in the amount of 40 to 367 billion Rupiahs in 2011 and was a bit lessen in 2012 with 
235 billion Rupiah. In 2014, foreign investment in Aceh began to increase even though it was still slow, and a jump in foreign investment occurred in 2016 which reached $\$ 8.8$ million from the previous 2015 below $\$ 1$ million (DPMPTSP, 2017). However, the highest foreign investment figure in Aceh is still the lowest number or ranking no 34, when compared to other provinces in Indonesia (Mukti, 2019).

Based on the facts described above, it shows that the province of Aceh has carried out paradiplomacy practices with various parties abroad, but it is still less effective for the development of the Aceh province. For a practice of paradiplomacy to work well and effectively, the collaboration must be with an interesting background. The background referred to is that a capital carried out in diplomacy is unique in the Aceh province. So far, what is commonly used in paradiplomacy practices are Aceh culture, student exchanges, and tourism. Paradiplomacy by using the three capital above (Aceh culture, student exchanges, and tourism) is still less effective in developing Aceh province.

Then, what capital can be used effectively in the practice of paradiplomacy to develop the province of Aceh? This paper will offer 3 main capital that can be used by the Aceh provincial government in the practice of paradiplomacy. These three capitals will have a significant effect because they depart from the background that is characteristic of Aceh Province. Thus, there will be no more collaboration carried out by the Aceh government which is not effective especially if it is only limited to the signing of the Memorandum of Understanding $(\mathrm{MoU})$.

\section{METHOD}

To analyse the problems in this study, we used a qualitative method, by gathering previous studies through observation, interviews and data collection from books, journals, news in newspapers and websites. Leedy and Ormrod (2013) further state that qualitative researchers construct an interpretive narrative from their data and try to capture the complexity of the phenomenon under study. Qualitative researchers thus use a more personal, literary style, and they often include the participant's language.

The data obtained will be analyzed to obtain facts about the main capital that can be used by the Aceh provincial government in conducting paradiplomacy practices. It also goes through a direct observation process to cities in the province of Aceh, such as the cities of Banda Aceh, Bireuen, and Central Aceh. From the 
results of this observation, a conclusion will be drawn about what kind of soft power can be used in the area as soft power diplomacy for use in paradiplomacy practices.

\section{RESULT AND DISCUSSION}

Paradiplomacy has been most visible in Western industrialized liberal-democracies. Quebec, Catalonia, the Basque Country, Flanders and Wallonia, as well as several German Lander and some French regions have all devoted considerable efforts at developing an international action. (Lecours, 2008). In India, state governments have negotiated directly with international financial organizations such as the World Bank, the Asian Development Bank and the United Nations Development Program, although these negotiations require the blessing of the federal government. In Malaysia, the state of Penang has actively been promoting itself as a centre for information and communication technology in SouthEast Asia (Loh, 2009).

The practise of paradiplomacy as commonly done by several local governments is the real implementation of soft-power diplomacy. (Mukti, 2019). According to Joseph Nye Jr. (2004), soft power is the ability to achieve what a state desired through the nation performance in the view of other States, and not by strengthening the force (military) or the payment (economic concession). Soft power has emerged from the performance of a country's culture, the political dream, and policies. If a state is willing to let its foreign policies seen 'legitimate' in the view of other nations, then the use of soft power is a must (Nye Jr, 2004).

Through the concept of paradiplomacy, Region and cities can create their opportunities by the potential of the region they have. Thus, the Region and cities will also more quickly resolve the problems they face and establish foreign relations with the parties they want. A region that has good potential to conduct foreign cooperation through the concept of paradiplomacy in Aceh Province, one of the 34 provinces in Indonesia.

Diplomatic activities take place in the negotiation process which also occurs bargaining. In this process, Power is needed so that it can be a determinant of bargaining positions. Sub-State (Provinces or Cities) does not have hard power as the state, then Province must have another power in the form of soft power, which will later become soft power diplomacy. This Power will be used in the practice of paradiplomacy. 
In carrying out the practice of diplomacy or paradiplomacy, an actor must have either hard power (military and economic power) or Soft Power (other than military and economic). Hard Power is only owned by the state, whereas soft power, this is what can be owned and used by regions / cities in a country to conduct diplomacy (paradiplomacy) with other regions / cities abroad.

Province has carried out various activities in the practice of paradiplomacy. However, as explained earlier that many of these paradplomacy activities did not go well or were limited to signing the $\mathrm{MoU}$, not reaching the implementation. Therefore, for a paradiplomacy practice to run effectively, the authority for paradiplomacy activities is also carried out by a city, in the concept of sister city or twice city.

It also needs to be explained that paradiplomacy is simply a form of activity, while the perpetrators of the activity are the provincial government or the city government in one region, be it in the form of sister province, sister city / twice city.

Aceh Province as one of the regions in Indonesia which has the potential thing to carry out cooperation abroad, Based on the Constitution and Constitution Number 11 of 2006 on the Aceh government, that has given Aceh province considerable authority to develop its territory, including establishing diplomatic relations with the regions others abroad through the Paradiplomacy practice.

To achieve this goal, we must identify the main capital that can be used by the Aceh provincial government or the city government to carry out paradiplomacy practices. Based on observations and interviews conducted at the office "Investment and Promotion Agency of Aceh (BAINPROM), it was found that the implementation of paradiplomacy practices did not use capital that has a high sale value and has a unique value in the province of Aceh.

Finally, what can be used as soft power diplomacy is the ability and culture inherent in Aceh province. In this paper 3 new capital will be explained which could become soft power diplomacy of the Aceh provincial government or cities in Aceh. These 3 things are Disaster of Tsunami/Disaster Mitigation Expert, Ex-Conflict Areas/Conflict Resolution Expert, world's best coffee producer.

\section{Utilizing the "Tsunami Disaster" as an Instrument of Paradiplomacy}

Disaster diplomacy combines two fairly common words. Definition in the Oxford Dictionary, 'disaster' is a 
sudden accident or natural disaster that causes great damage or loss of life. The second word, 'diplomacy', at the basic level contrasts with a war where diplomacy is interpreted as the peaceful side of politics, where negotiation is the path of choice for a change.

When two words are used at the same time, it is an attempt to give birth to a new idea about how a disaster can be used for diplomatic means at the national and international level. One of the figures who supported the development of this idea came from Ilan Kelman (2011) who contributed a lot in the form of reports and articles on disaster diplomacy, all of which culminated in his 2012 publication on disaster diplomacy, Disaster Diplomacy 'How disaster affects peace and conflict'.

Kelman's view of the disaster diplomacy is how a disaster can provide opportunities for cooperation in building peace. These opportunities manifest themselves in both times before and after a disaster, which means that any cooperation related to disaster is understood to be part of disaster diplomacy. As an illustration of pre-disaster activities, one successful example of cooperation from the disaster base is the collaboration of American and Cuban scientists on providing a storm monitoring system. Basically, America and Cuba are hostile countries, but because there is a similar problem, the storms, it can be used as a diplomatic tool for peace (Novialdi, 2016).

A similar thing happened in the Aceh Province, the tsunami disaster became the capital used as a diplomatic tool to resolve Aceh's conflict with Indonesia and also to revive the economy. But more importantly, because of the tsunami that occurred in Aceh, making Aceh as one of the regions in the world with good disaster mitigation. A disaster, if managed properly, will be a productive source of political and economic diplomacy, as explained by Surwandono and Herningtyas (2019) that natural disasters can be positive social capital to solve social, economic, political and socio-cultural problems in vulnerable areas disaster. Therefore, the Aceh government must actively participate in disaster diplomacy activities and develop new strategies to manage and utilize the 2004 tsunami to be an asset in development.

Kelman (2016) argued that disaster diplomacy can be successful when those in power decide that they want to succeed and then use their strength for that purpose. In Aceh Province, there are various kinds of facilities that support disaster mitigation, especially from the tsunami disaster. Intended facilities such as tsunami sirens, evacuation routes, 
escape the building, and Tsunami and Disaster Mitigation Research Centre (TDMRC) in Universitas Syiah Kuala (Unsyiah). With this disaster mitigation capability, it can become the capital of Aceh Province in increasing cooperation in the field of overcoming the tsunami disaster. Province of Aceh (through Banda Aceh Government) has established cooperation with Japan in the field of disaster mitigation (Junaidi, 2018).

Based on interviews with BAINPROM, they explained that so far in international forums participated by the Aceh provincial government, they often played videos when the tsunami struck and the post-tsunami condition of Aceh (about governance, especially about disaster mitigation) (Risky. N (Interviewer) \& Junaidi (interviewee). (2016)). This effort can be an attraction for other provincial governments abroad who are interested in learning about disaster mitigation. Thus, this attraction can be used by the Aceh Province as a instruement of paradiplomacy.

In the future, the province of Aceh can establish cooperation with regions in other countries that have the potential for earthquake and tsunami threats, such as regions in Malaysia, Sri Lanka, and India. It is also possible to collaborate with regions that also border the oceans in the Americas, Europe and Africa. All this will depend on the promotion process and the exploration of cooperation with these parties by the Aceh provincial government and the city government in Aceh.

\section{Utilizing Aceh Image as a Conflict Resolution Expert as an Instrument of Paradiplomacy}

The province of Aceh once experienced a 'separatist' conflict between the Aceh Sumatra National Liberation Front (GAM) and the Republic of Indonesia (NKRI). GAM clearly represented Aceh's claim to independence, not just in historical terms as 'the Acehnese to armed resistance in the form of the Islamic organization of Darul Islam (DI) claimed,' but also in terms of racial exclusivity, and at least regarding the Javanese. (Kingsburry, 2012). The conflict from 1976 to 2004 has claimed many victims both from the military and civil society. However, in 2005 something previously imagined was almost impossible, peace ensued between the two sides and ended the conflict forever.

Previously, GAM demanded independence from Indonesia, while from the Indonesian side hoped that Aceh would remain within the territory of the Indonesian state. The signing of the $\mathrm{MoU}$ in Helsinki, ending the war between the two and Aceh finally returned totally to Indonesian 
territory. The agreement reached was not easy, but had gone through a very complicated and detailed process. Besides, the intelligence and maturity of both parties were the supporting factors for reaching an agreement.

The peace process in Aceh has notched up significant achievements, including the demobilisation of the GAM and the withdrawal of troops by the Indonesian government, while the passing of the Law on the Governance of Aceh has enabled local political parties to develop, thereby ensuring greater decentralisation and democracy. In the 2006 elections, Irwandi Yusuf, a former member of the GAM, was elected the Governor of the autonomous province of Aceh. Of course, concerns remain regarding the peace process, given sporadic conflict among ex-GAM members as well as the Indonesian state and the military in transition. One of the principal reasons for the failure of the peace process in Sri Lanka was that the government which signed the peace process was voted out of the office and the new government abrogated the peace agreement. (Senanayake, 2009). But what happened in Aceh, has placed the position of Aceh with maturity as an actor in diplomacy.

Lee (2020) viewed that a clear and illiberal approach to peace building causes an end to hostilities and peace in Aceh. From this fact, it puts Aceh as a guideline for other countries involved in the separatist conflict with the provinces in their regions, such as Sri Lanka, the Philippines, Thailand, Myanmar. Aceh Province can offer itself as a mediator and cooperation to help conflict areas.

Based on the discussions we had with Drs. Nurdin Abdurrahman, MA, who was a GAM negotiator during the peace negotiation with Indonesia in Helsinki, Finland. He explained that he had been asked as an expert to resolve the conflict that occurred in Mindanao, Philippines. The conflict in Mondanao was almost similar with Aceh, which involved the central government and the province (Nurdin Abdurrahman, Personal Communication 2019, July 19). This shows that Aceh Province can be used as a reference as an example of conflict resolution, especially related to separatist conflict.

Thus, this capability can be used as a instrument of paradiplomacy (as a Soft Power Diplomacy for the Province of Aceh) by the Aceh provincial government, when establishing diplomatic relations with other provinces abroad, especially Provinces that have the same conflict problems with Aceh Province. 


\section{Utilizing Aceh Image as the World's Best Coffee Producer as a Paradiplomacy Instrument}

Food (coffee) reflects its role in human relations, various aspects of life such as social, economic, political, mental, nutritional, and moral are influenced by food. This is because food is a widespread social phenomenon, it cannot be approached by one discipline. (Fregulia, 2019). The same thing was also expressed by Intentilia (2020) where he stated that coffee is one of the commodities used by the government to promote culture abroad, while at the same time this trading product has potential value to support the country's economy. Therefore, it cannot be denied that coffee is a very valuable capital in supporting the economic sustainability of the government.

In particular, Aceh has the privilege of being a region with highquality coffee commodities in the eyes of the world. Based on data released by the International Coffee Organization (2019), Indonesia is ranked as the fourth largest coffee producing country in the world after Brazil, Vietnam and Colombia. Aceh as part of Indonesia contributed about $10.27 \%$ in 2017 , the third-largest after South Sumatra and Lampung (Badan Pusat Statistik, 2017).

Most coffee commodities in Indonesia are dominated by Robusta- type coffee. Meanwhile, Aceh, together with Sumatra Utara, is leading the Arabica coffee production centre in Indonesia. Given the fertile soil, the two regions are overgrown with diverse coffee vegetation, and the most famous of which is Kopi Gayo which is the pride of the Acehnese people.

This coffee has crossed the country to get the title as one of the world's best coffee. This is evidenced by the achievement of Fair Trade Certified $^{\mathrm{TM}}$ from the organization of International Fair Trade and entered as the world's best coffee nomination at the International Conference on Coffee Science in the same year. Not only that, but Kopi Gayo also has the highest selling price at the world coffee exhibition held by the Specialty Coffee Association of America (SCAA) organization at the Portland Oregon Convention Center, United States. The famous Kopi Gayo certainly cannot be separated from its distinctive taste, has balanced acidity with a level of thickness that tends to be mild.

Talking about instrument of paradiplomacy, one thing that cannot be missed is the fact that Aceh is the best coffee producer in the world. Of course this can be used as an ingredient in exploring international cooperation with other coffeeproducing provinces abroad. Based on the results of an interview with $\mathrm{Mr}$. 
Junaidi, a staff at BAINPROM, he explained that up to now the mainstay of cooperation between the province of Aceh and abroad is in the coffee sector (Risky. N (Interviewer) \& Junaidi (interviewee). (2016) ). So, coffee has been used by the Aceh government in an effort to build relations of foreign cooperation, so it seems that the government understands the importance of coffee as an important instrument in the practice of paradiplomacy.

\section{CONCLUSION}

In the era of globalization, the local government must be able to take advantage of all forms of opportunity to develop its territory. They cannot just rely on assistance from the central government. Through the practice of paradiplomacy, Aceh government is able to establish cooperation with other provincial governments abroad in accordance with Law Number 11 of 2006 concerning the Government of Aceh. Moreover, to carry out a practice of paradiplomacy, it is need to have capital so that it can be used in diplomacy (soft-power diplomacy), and Aceh is provinces that have the authority and has a lot of capital in diplomacy.

Under Constitution of 2006 on the Aceh government, it gave a considerable amount of authority for the Aceh provincial government to practice paradiplomacy. Thus, Aceh must also have the power to conduct diplomacy and strengthen its bargaining position with other provinces abroad.

To conclude, Aceh Province has several powers as capital in the practice of paradiplomacy, including Disaster of Tsunami/Disaster Mitigation Expert, Ex-Conflict Areas/Conflict Resolution Expert, and World's best coffee producer. These three soft power are not a limitation for Aceh province. Aceh has a lot of other forces such as regions that implement Islamic law, Halal tourism areas, and so on. By practising paradiplomacy and using existing soft power diplomacy, the province of Aceh can become an advanced region in the future, like Catalunya, which is one of the regions in the world that is very successful in the field of paradiplomacy.

\section{REFERENCES}

Badan Pusat Statistik. (2017) Statistik Kopi Indonesia 2017 (Online). Available at: https://www.bps.go.id/publication/20 $18 / 12$ /20/71e7ada61b13e59be0b1bf80/statis tik-kopi-indonesia-2017.html (Accessed: 20 December 2018).

Berridge, G. R. (2015) Diplomacy: Theory and Practice. London: Palgrave Macmillan.

DPMPTSP. (2017) Perkembangan Realisasi Investasi Aceh Tabun 2010-2017 (Online). Available at: https://dpmptsp.acehprov.go.id/id/inf 
o-publik/data-investasi/ (Accessed: 27 August 2019).

Fregulia, J. M. (2019) A Rich and Tantalizing Brew: A History of how Coffee Connected the World. University of Arkansas Press.

Ganie, S. A. (2015) Diplomasi Ekonomi Aceh. Aceh Trend (Online). Available at: www.acehtrend.com/2015/12/08/ diplomasi-ekonomi-aceh/ (Accessed: 05 December 2015).

Intentilia, A. A. M. (2020) Coffee Diplomacy in Jokowi's Era: The Strategy of Cultural and Economic Diplomacy of Indonesia's Foreign Policy. Jurnal Ilmiah Dinamika Sosial, 4(1), 63-81.

International Coffee Organization. (2019). Coffee Market (Online). Available at: http://www.ico.org/ documents/cy2018-19/cmr-0719-e.pdf (Accessed: 19 December 2019).

Junaidi, H. (2018). Banda Aceh Perkuat Kerja Sama Mitigasi Bencana dengan Jepang (Online). Available at: https://bandaacehkota.go.id/berita/10 065/banda-aceh-perkuat-kerja-samamitigasi-bencana-dengan-jepang.html (Accessed: 12 August 2019).

Kelman, I. (2011) Disaster Diplomacy: How Disasters Affect Peace and Conflict. London: Routledge.

Kelman, I. (2016) Catastrophe and conflict: disaster diplomacy and its foreign policy implications. Brill Research Perspectives in Diplomacy and Foreign Policy, 1(1), 1-76.

Kingsbury, D. (2012) Diversity in Unity. In Autonomy \& Disintegration Indonesia (pp. 113-128). London: Routledge.

Kuznetsov, A. S. (2014) Theory and Practice of Paradiplomacy: Subnational Governments in International Affairs. New York: Routledge.

Lecours, A. (2008) Political Issues of Paradiplomacy: Lessons from the Developed World. The Hague: Netherlands
Institute of International Relations Clingendael.

Lee, T. (2020) "Political orders and peaceBuilding: Ending the Aceh Conflict. Conflict, Security \& Development, 20(1), 115-139.

Leedy, P. D., \& Ormrod, J. E. (2014) Practical Research: Planning and Design. New York: Pearson Education.

Loh, F. (2009) Federation of Malaysia. Foreign Relations in Federal Countries, 5 , 188-210.

Mukti, T. A. (2019) Paradiplomacy and the Future of Aceh Government. In 1 st Aceb Global Conference (AGC 2018). Atlantis Press.

Novialdi, R. (2016) Pengarub Bencana Tsunami Terbadap Peningkatan Soft Power Diplomacy Pemerintah Provinsi Aceh Tabun 20042015. Dissertation (Online). Available at: http:// repository.umy.ac.id/handle/12 3456789/2678 (Accessed: 20 December 2018).

Nye Jr, J. S. (2004) Soft Power: The Means to Success in World Politics. Public affairs.

Rodrigues, G. M. A., \& Mattioli, T. (2017) Paradiplomacy, Security Policies and City Networks: The Case of the Mercocities Citizen Security Thematic Unit. Contexto Internacional, 39(3), 569587.

Senanayake, D. R. (2009) International Aid, Peace-building and Conflict: Lessons from Aceh and Sri Lanka (Online). Available at:

http://citeseerx.ist.psu.edu/viewdoc/s ummary?doi=10.1.1.601.685 (Diakes: 27 Agust 2019).

Surwandono, S., \& Herningtyas, R. (2019). Shifting Actors and Strategy in Indonesia's Disaster Diplomacy After Tsunami Aceh 2004. Jurnal Ilmiah Hubungan Internasional, 15(2), 185-196. 
Tavares, R. (2016). Paradiplomacy: Cities and States as Global Players. Oxford University Press.

Wolff, S. (2007). Paradiplomacy: Scope, Opportunities and Challenges. The Bologna Center Journal of International Affairs, 10(1), 141-150. 